IJLR: International Journal of Law Recontruction

Volume 5, Number 1, April 2021

DOI : http://dx.doi.org/10.26532/ ijlr.v5i1.11295

\title{
THE IMPLEMENTATION OF HUMAN RIGHTS IN LABOUR AND HUMAN TRAFFICKING LAW ON WOMEN
}

\author{
Sulistyowati \\ Muria Kudus University \\ sulistyowati@umk.ac.id
}

\begin{abstract}
This study aims to analyze implementation of human rights in economic field and role of the Government, Educational Institutions and Non-Governmental Organizations in the prevention and control of trafficking in women. How to achieve the goal, is done by empirical studies and documentation studies, to obtain primary and secondary data. This research is descriptive analytical. The approach method used is empirical juridical. Data analysis was carried out in a qualitative descriptive manner. Factors that cause the implementation of human rights in the economic field have not been fully realized because between legal policies and legal implementation have not been running consistently and simultaneously. The realization of human rights in the economic field is still only limited to issues and has not become a concrete implementation. The role of the Government in the prevention and overcoming of trafficking in women is still limited to political will by the issuance of a law that ratifies the ASEAN Convention Against Trafficking in Persons, Especially Women and Children, then followed by Institutional Infrastructure Compilation. The role of Educational Institutions and Non-Governmental Organizations in the prevention and prevention of trafficking in women, has responded with action, prevention and handling of trafficking in women, through the socio-economic empowerment of families and advocacy in handling cases of trafficking in women. The struggle and movement for the achievement of feminism justice, in the economic field is carried out by empowering the family economy, improving education and expanding access to job search for women by utilizing information technology.
\end{abstract}

Keywords: Human Rights; Women; Workers; Human Trafficking.

\section{A. INTRODUCTION}

Human rights are a universally recognized right, as a human right, because of the Nature and natures of human. It is said to be Universal because these rights are expressed as part of every humanity. Human rights have never differentiated skin color, social background, religion, age and gender difference of both male and female. ${ }^{1}$ Human rights are referred to in humans, because

1 Soetandyo Wignjosoebroto, Hak-Hak Asasi Manusia: Konsep Dasar dan Pengertiannya Yang Klasik pada Masa-Masa Awal Perkembangannya,dalam Toleransi dan Keragaman: Visi untuk

IJLR, Volume 5, Number 1, April 2021 
those rights are owned by anyone who was born because of his nature as a human, not because of the provision by any organizations or authorities. Human rights are inherent, and basically the right - this right is not allowed and no one can be robbed or revoked by anyone. ${ }^{2}$

Human Rights Implementation holds 3 (three) main principles ${ }^{3}$, namely (1) universality, meaning that Human rights belong to all people because of its nature as a human, not May be treated differently due to racial differences, skin color, religion/ beliefs, social status and gender; (2) equality and without discrimination, which means that every person is born free and has the same right without being relieved for some reason; (3) The indivisibility and interdependence of different rights, intended that in the framework of the fulfillment of human rights, cannot be severed between the fulfillment of civil and political rights with the fulfillment of economic, social and cultural rights. This is because the scope of these two areas of entitlement cannot be separated between each other. In this sense to ensure the fulfillment of minimal standards namely economic, social and cultural rights is very important in the effort to ensure can enjoy it civil and political rights. Conversely, the development of civil and political rights could not be waived from the fulfillment of economic, social and cultural rights.

The debate on human rights values, in their implementation in every country is not Universal. This is because the values of human rights in each country are very contextual because of the Association with cultural values that grow and develop Dynamic. ${ }^{4}$

The implementation of human rights in the economic field specifically in the country of Indonesia, especially against women, still has not materialized optimally. This is because there are some laws and regulations that do not put women in Indonesia cannot maximize potential of self to exploit the maximum economic achievement. ${ }^{5}$ The Indonesian women are not positioned as a responsible for the fulfillment of the family Economy, such as in the marriage law mentions that the responsible to fulfillment of the economy of the family is a man or husband and not a woman or wife. The issue is much happening when in its reality, the support of the economic backbone is women or wives. Women or wives emerge as a person who has to be responsible for the empowerment and sustainability of the family Economy, with all the limitations of Resources owned and there is virtually no comparative advantage on offer.

Abad ke-21 Kumpulan Tulisan tentang Hak Asasi Manusia, Pusat Studi Hak Asasi Manusia, Surabaya dan The Asia Foundation, Surabaya, 2003, Page. 4

2 Ibid.

3 A. Widiada Gunakaya, Hukum Hak Asasi Manusia, Penerbit ANDI, Yogyakarta, 2017, page. 6167.

4 Rosyada, Dede, Pendidikan Kewargaan: Demokrasi, Hak Asasi Manusia dan Masyarakat Madani, Prenada Media, Jakarta, 2003, page. 23

5 Maftukhatusolikhah, Dwi Budiarto, Pemberdayaan Ekonomi Perempuan Perspektif Gender dan Ekonomi Islam: Studi Kasus Akses Pengusaha UMKM Perempuan Terhadap Lembaga Keuangan Syariah BMT Di Palembang, I-Finance, Volume 05 No. 01, July 2019, page. 44 
The insecurity of human rights violations in the economic field for women is generally caused by several factors, such as poverty, Low education and early childhood. The chain of human rights violations in the economic field for women, will be closely related to the phenomenon of trafficking in women with camouflage placement of Labor Indonesia, both domestically and abroad. The Exploitation and export of women to foreign workers who are without adequate skill and skills will lead to women's trade transactions. The trading transactions of women are potentially enormous for human rights violations especially in the economic field, because they work with long working hours and inadequate wages. All of them are prone to physical, mental or sexual abuse. There are many factors that trigger and cause the practice of women's trafficking, but in principle There are 3 (three) basic things namely poverty, low education and married early age. These three are synonymous with the indicator of human rights violations in the economic field for women. ${ }^{6}$

The first cause of women trafficking is economic poverty. ${ }^{7}$ Poverty is regarded as an important factor in the cause of human rights violations in the economic sphere and is the cause for the trade of prequality. The poor women will have the limitations of options for sourcing livelihoods and they also have little social power to control social conditions and structural presses itself. The Desire to improve the condition of poverty, often makes many women Choose to migrate. Migrations occur, both interregional and intercountry migrations. The Limited information and ignorance of the region or country of destination and desire to improve fate, they face the risk of women's Trade. ${ }^{8}$ The research done by Johanna Debora Imelda, Indramayu District, Indonesia, gives data that $76 \%$ of Women Labor is derived from Poor families with data $53,7 \%$ their parents ' work was a peasant laborer with an average family of 5 (five) people. Such Data, can provide reference references that the Labor of women is from poor families. ${ }^{9}$

Indonesia, being one of the senders of female Labor to various Middle Eastern countries such as Saudi Arabia, Jordan and Abu Dabi, while in Asian countries, such as: Hongkong, Malaysia and Singapore. Indonesia's female work force, being one of the opportunities and objectives for the opening doors of women's trafficking. This condition is caused by those who migrate the

6 Marcellena Nirmala Chrisna Moer, Idin Fasisaka, Putu Titah Kawitri Resen, Implementasi Protokol Palermo Dalam Menanggulangi Permasalahan Tenaga Kerja Wanita Indonesia Yang Menjadi Korban Human Trafficking, Jurnal Hubungan Internasional, Vol 1 No 1, 2016, page.2-4

7 Siti Zakiyatul Humairo, Trafficking Woman And Child (Sebuah Kajian Terhadap Hadis-Hadis tentang Trafiking pada Perempuan dan Anak), Martabat: Jurnal Perempuan dan Anak, Vol. 02, No. 01, July 2018, page.179-180

8 Abu Hanifah, Perdagangan Perempuan dan Anak: Kajian Faktor Penyebab dan Alternatif Pencegahannya, Sosio Konsepsia, Volume 13 No.2, 2008, page. 53-54

9 Ibid. 
majority have poverty problems, both subjective poverty, absolute, natural, cultural and structural poverty. ${ }^{10}$

Quantitative and qualitative poverty existed in developing countries, including Indonesia, due to the pace of uncontrolled population growth, high unemployment rate due to the narrow employment, low levels of education, Natural disasters, even distribution of Natural Resources and Economic policies of governments that tend not to gender sensitive. ${ }^{11}$

To solve the problem of high poverty rate, has been done with economic Empowerment Strategy. Countries can structurally create new employment opportunities in line with natural population growth. The phenomenon of gender-based economic inequality is still occurring in developing countries, including Indonesia. Although in many ways Indonesian women have had the same opportunity with men. Protection and enforcement as the expression of gender justice in various occasions is indispensable. Protection and enforcement are indispensable, both in terms of education, information and other self-capacity enhancement efforts so that Poor people have the opportunity to access Natural Resources and development results are easy and not discriminatory. The country's budget and expenditure allocation is proportionately aimed at improving Human development, economics and infrastructure. During this development tends to be more physical-oriented infrastructure that is automatically expected to improve the economy, but not done Human Development as the lead actor in the development of community and Nation. The gender Responsive budget policy has not been able to color the budgeting political process in General.

The second cause of female trafficking is due to low education. ${ }^{12}$ The low level of education is also a contributing factor to the occurrence of female trafficking. In the community and culture of a country that emphasizes the values of patriarchy, girls or women are placed as second-class citizens, while men placed as a first class citizen. The values of the living and developing patriarchy in a Nation will have an effect that take precedence over gaining a higher education. In Indonesia, such conditions exist and develop in rural areas with low parental status and education. ${ }^{13}$

To address problem of low education of women, in Indonesia through the Ministry of Education and culture has taken legal policies and regulations regarding compulsory learning 12 (twelve) years. This policy requires all Indonesian children to attend at least 12 (twelve) years of age, or the equivalent of high school with funds sourced from the budget and state spending revenue. This policy is one of the solutions to cut poverty chains due

10 Ike Sylvia, Faktor Pendorong Dan Penarik Perdagangan Orang (Human Trafficking) Di Sumatera Barat, Humanus, Vol.XIII, No.2, 2014, page.195

11 Ibid, page. 196

12 Ike Sylvia, Ibid., page.196

13 Abu Hanifah, Op. cit, page. 56 
to educational factors. In addition to increasing education, people can access information, knowledge and job field more easily. ${ }^{14}$

The third cause of female trafficking is to marry early age. In many cases in Indonesia, parents with low educational and social status as well as poor economic conditions, encouraged his daughter to marry at an early age. The consideration of parents married his daughter at an early age was to quickly reduce the family economic Burden and turn to the child's husband. Marriage in Indonesia, regulated by Act No. 1 of 1974 on marriage, requiring the first married age to a male - minimum 19 years old and female minimum 16 years old. The age limit of this marriage is then carried out the material test to the constitutional court, and has been decided by the constitution court with the verdict No. 22/Puu-XV/2017 minimum age limit Married to men still remain at the minimum age of 19 years and females at least 16 years old to a minimum of 19 years equal to the limit minimum of males. ${ }^{15}$ While the results of Research conducted by the State Islamic University of Jakarta, Indonesia (2000-2007), uncover the fact that the ideal marital age maturity for males is 24 years and women 20 years. ${ }^{16}$ The maturity of this age resulted from the accumulation of indicators about the readiness of physical, economic, social, mental, psychiatric, religious and cultural.

Marriage at an early age for women poses a variety of risks and impacts, both biological as damage to the reproductive organs and young pregnancies. Risks and Other impacts may be a psychological risk of inability to carry out family functions and the inability to overcome family economic difficulties. This condition will trigger a high Divorce rate, and the effect of women should be responsible independently to meet the family's economic needs. Hence, one of the consequences women of divorce victims into domestic or foreign workers is vulnerable to the case of women's trafficking.

To address the issue of early childhood marriage for Indonesian women, by continuously providing socialization of marital Law and the minimum limitation of marriage based on Court ruling Constitution. Provision of facilities and assistance of operational funds to continue higher School so that women are not easy to decide to marry in the early age for economic and poverty reasons.

The narrow field of work in the Country and its small salary received for female workers in the country is the cause of the many women who have to work abroad, both legal or illegal. Most Indonesian working women work in the

14 Asih Widi Lestari, Andy Fefta Wijaya, Siti Rochmah, Implementation of Compulsory Study 12 Year Policy to Increase Education Quality in Kudus Regency, Wacana, Volume 18 No. 1, 2015, page.3

https://www.mkri.id/public/content/persidangan/putusan/22 PUU-XV 2017.pdf accessed on January 2021.

16 Akhmad Shodikin, Pandangan Hukum Islam Dan Hukum Nasional Tentang Batas Usia Perkawinan, Mahkamah, Volume 09 No. 1, January-June 2015, page. 120 
informal sector, due to the lack of skills and education They have. Women of informal and illegal workers working abroad often become victims of violence, trafficking (human sales) and other injustices that have to lose their lives. During this time the number of women who became overseas workforce more than $50 \%$ came from Indonesia. ${ }^{17} \mathrm{~A}$ total workforce of 9 million, spread across several countries such as, $55 \%$ in Malaysia, $13 \%$ in Saudi Arabia, 10\% in China and other countries.

Human rights that do not work properly, impact on economic rights and indirectly encourage problems such as women's trafficking into focus Attention and struggle to bring gender justice from policy, and its implementation in the life of Society broadly. These complex and complex issues will be the topic of discussion in this organized panel discussions. Our expectations of this panel discussion forum, can contribute based on the experience of facing and addressing similar problems in various countries where participants attend.

\section{B. RESEARCH METHODS}

The research methodology used in this article is descriptive analysis with an empirical approach. The empirical approach is a research approach that is used to describe the conditions seen in the field as they are. ${ }^{18}$

\section{RESULT AND DISCUSSION}

\section{Human Rights Implementation In Economic Field}

In normative Human rights, especially in the field of economics, each country has set it both through the Constitution, and its derivatives and technical implementation in each Ministry concerned. In Indonesia, all regulatory devices are already available and adequate. The problem always arises in the Implementation of the administration, because of weak Law enforcement. The Main problem in Indonesia is the implementation of policies that have not been thoroughly responsive gender. In Indonesia, Commitment to realize equality and Gender Justice in all aspects of life has been published in the presidential Decree No. 9 of 2000 on gender mainstreaming. All rules of implementation, from planning to budgeting have been compiled, and to the stakeholders at all levels of government, from the Central Government To local governments. The problem is not easy, because the mainstreaming of gender requires planning to budgeting and monitoring and evaluation of the implementation of activities in the field

17 World Bank, Woman Entrepreneurs In Indonesia A Pathway to Increasinf Shared Prosperity, 2016. $\quad$ https://documents1.worldbank.org/curated/en/738881467782741648/pdf/AUS5568P147245-PUBLIC-WomenEntrepreneursinIndonesia-1.pdf accessed on January 2021

18 Suharsimi Arikunto, Prosedur Penelitian Suatu Pendekatan Praktek, Rineka Cipta, Jakarta, 2006, page. 142 
that gender sensitive. ${ }^{19}$ Many occur among the stakeholders is a neutral ideology and a gender bias.

Gender sensitivity is an ideology that puts male and female gender equally and fairly. ${ }^{20}$ In the implications of a person who does not have gender sensitivity will be difficult to direct the program, since the planning and budgeting, implementation, monitoring and its evaluation is perspective Gender very difficult. The other problem is that in Indonesia, public officials have the opportunity, and the rules of the invitation govern for the mutation, promotion or demotion. Therefore, officials who have a gendersensitive perspective as the impact of training or sociological perception, will leave its place due to mutation, promotion and demotion and are replaced new people with a new paradigm again, which is not necessarily gender sensitive.

Gender ideology, whether sensitive, biased or neutral gender is formed through the accumulation of values and norms in Society, and is followed by generations in the process of transforming value in the family. The issue arises because of the culture of the Patriarchy of Society that puts the position of women in the Society as a second class citizen (subordination). ${ }^{21}$ This has an impact on gender inequality in many aspects of life. According to an analysis Pathway a gender role can be seen from its access, benefits, participation and controls. Gender inequality can occur in women and men but to This day, more and more impacts are women and girls, only a little man.

Women, most do not have an adequate Understanding of human rights in the field of economics and its enforcement. This is because there are still many who have Low education, especially in rural areas or in societies that still hold ancestral culture and customs firmly. ${ }^{22}$ Sometimes a gender inequality occurs, but considers it as appropriate or natural and should be. Despite the recognition of fundamental rights of Indonesian citizens, explicitly contained in the Constitution of the Republic of Indonesia 1945.

An Economic, Known As Rights Basic Economic Social and Culture (Rights). Content From Article About Rights Human In Field Economic That Stated in Constitution Country of Indonesia 1945, Including:

19 Shinta Dewi Rismawati, Pembangunan Hukum Yang Berkeadilan Gender (Pendekatan Studi Hukum Kritis Bagi Perlindungan Hak Asasi Perempuan Di Indonesia Pasca Ratifikasi CEDAW), Muwazah, Volume 3 No. 3, December 2011, page. 436

20 Carmen Martínez, Consuelo Paterna-Bleda, Masculinity Ideology and Gender Equality: Considering Neosexism, Anales De Psicología, volume 29 No. 2, May 2013, page. 559

21 Ni Nyoman Sukerti, I Gusti Ayu Agung Ariani, Gst. A. A.Ari Krisnawati, Implikasi Ideologi Gender Dalam Hukum Adat Bali (Studi Di Kota Denpasar), Jurnal Magister Hukum Udayana, Volume 5 No.4, December 2016, page. 811-812

22 Sippah Chotban, Azis Kasim, Ketidakadilan Gender Perspektif Hukum Islam, Al-Risalah, Volume 20 No. 1 , November 2020, page. 35-36 
a. Every people reserves education and won benefits from science knowledge and technology, art and culture by increase quality life and by welfare people human;

b. Every people reserves to work and got rewards and treatment that fair and worth in relationship work;

c. Every people reserves good life, housed live and receive environment life that good and healthy and reserves obtain service health;

d. Every people reserves got ease and treatment special to obtain opportunity and benefits that same to reach equation and justice;

e. Every people reserves top guarantee social that allows development himself an intact as human that dignified;

f. Economy compiled as business together based top basic family;

g. Branch production that important for countries and life of people controlled by the state;

$\mathrm{h}$. Earth and water and wealth natural that contained in it controlled by the country and used to charge of-great prosperity people. From eight things the in top by the Indonesian state a juridical formil have expressly explicit in in constitution country of Indonesia.

However, in implementation yet fully manifest with good. As fulfillment features country law that democratic, which is including should give guarantee rights human in field economic, besides in field political, civil, social and culture.

In terms of basic needs, economically, socially and culturally simply including fulfillment of clothing, food, Board, and Employment. Both women and men have the same right to get them. The ease of access is not only seen in the system, its institutional, and its processes but also the adequacy or availability. ${ }^{23}$ The availability of food and clothing, there are still a few people who have not been able to access due to the limitation of purchasing Power, affordability due to the mileage of the village market still far away and access road and Transportation infrastructure is not adequate. ${ }^{24}$ It is experienced by the people in the outlying Islands and still isolated. The Government has strived to overcome with the development of cross roads and or translucent roads in many parts of Indonesia which is very wide compared to Other ASEAN countries. On the other hand Indonesian people in General have been able to access basic needs of eating and clothing quite and easily either with the facilities off line and on line.

Like for Board needs and infrastructure, most settlements as a family need have not been designed by adjusting the occupants widely. Even decision-making related to home and other infrastructure has not involved the wishes and needs of both men and women as residents explicitly. In Indonesia, under the provisions of the Act No. 1 of 1974 about marriage

23 Wiwik Sri Widiarty, Perlindungan Hukum Persamaan Hak Asasi Perempuan dalam Meningkatkan Perekonomian Indonesia, Tô-râ, Volume 3 No. 3, December 2017, page. 643 24 Ibid. 
that indeed provides shelter (home) is the obligation and responsibility of the husband (Male so it has an impact on the undoing of women's involvement to determine and to choose a home that would become a common place to dwell and be housed to stay. ${ }^{25}$

Implications for employment for women in the informal or domestic sectors, prone to human rights violations. In the domestic and Informal sectors of Women Labor, many violations of human rights such as physical, mental, and working hours exceed 8 (eight) hours a day, unpaid salary, sexual harassment, not given time to worship, no opportunity to contact with its environment and closure Communication access for her family. ${ }^{26}$ Socio-Cultural Development, gender Empowerment indicators measured by the number of women being executives and business departments. Indonesia already many women who occupy in executive offices and business departments, but it is not easily acquired. Need hard struggle and must have the advantages and priorities of the competencies that are not owned by the men as competitors. Political developments, women in Parliament are more tangible implementation. This is evident from the fact in the whole of Indonesia that very small amount given the opportunity, support and equality of the right to occupy the position of good parliamentary leadership as Chairman or vice-chairman. Equally rare women are given the opportunity, support and similarity of rights to occupy the position of leadership of parliamentary fittings, such as the chairman of the Commission, Chairman of the Budget and Chairman of the legislation Board.

There is a false understanding and Understanding of Gender bias as though the political World and Political Office is its rank and male's domain man. The dichotomy and ambiguity of understanding existence of the world of men and women in political atmospheres makes the struggle of women in the political world more extra than men. ${ }^{27}$ In practice in the political world when men can occupy political offices in Parliament only on condition $\mathrm{x}$, women still have to struggle with the $x$ plus requirements, because when only the $x$ is like a man, then the woman will be searched-find the side of the weakness that is naturally attached to the anatomy of women, although It is not always true.

In general, the constitution as a basic rule, consists of two distinct sections, namely the formil and the material part (Manfred No Wak, 2003). The formil section of the Constitution contains rules relating to the State agencies or institutions and the underlying structural Principles of the State, such as the separation of power and governance system. The Constitutional material contains about the values, intentions and objectives that the State

25 As stated in Article 34 Paragraph (1) of Law Number 1 of 1974 concerning Marriage.

26 Nurul Husna, Kekerasan Terhadap Perempuan Sebaga Pekerja Migran, Jurnal Al-Bayan, Volume 21 No. 30, July-December 2014, page. 12-13

27 Irwan Abdullah, Politisasi Gender Dan Hak-Hak Perempuan Kendala Struktural Keterlibatan Perempuan Dalam Pencalonan Legislatif, Palastren, Volume 7 No.2, March 2016, page. 20 
and Human rights are about to achieve. Indonesian Constitution, specifically in the material section, by the founder of the Nation idealized state of Indonesia as a state of Law, which is based on the law. The assertion of the state of Indonesia state of Law, explicitly expressed in the explanation of the Indonesian Constitution.

The affirmation of Indonesia as the state of law, accompanied by the arrangement of Human rights wider and comprehensively listed in the articles of the Constitution of the state of Indonesia. In These chapters all aspects of human rights are secured, including Human rights in the field of economics or Human rights supporting the fulfillment of human rights in economy is a human right to acquire a livelihood and a decent job for humanity and Human rights to achieve prosperity. Human Rights arrangement, in the Constitution of the Indonesian state, namely the Constitution of the Republic of Indonesia 1945, is a form of State Commitment to qualify the existence of Indonesia as the country Law (the consultative Assembly of the Republic of Indonesia, 2011).

The guarantee and protection of human rights, which have been listed constitutionally, is not a guarantee that the implementation of human rights, will certainly be respected and executed with consistently. A guarantee at the constitutional level of a country, only as the norm governs and acknowledges legally formal, that Human rights are present and recognized and protected by the state. Implementation of human rights, very dependent on the political will of the government in real, consistent and immutability. It is also dependent on the availability of Institutional Infrastructure, mechanisms of achievement of human rights implementation and the commitment of State organizers to be Fair and not discriminatory to fulfill The rights of its citizens. Development of Concepts of understanding of human rights, must encourage all countries of the world to make a concept of change to the constitution of the country, to continue to be up date of recognition of rights Human rights, for all its citizens. ${ }^{28}$

The development of the concept of understanding of Human Rights, which originally emerged pluralism is now also appears to be understood pluralism and partiality simultaneously. The position of the country that initially raised hands and did not intervene now must intervene and facilitate and empower lives of its citizens especially in terms of fulfillment and Implementation of human rights in the economic field. Human rights understanding that once was only oriented to the realization of rights in the field of civil and political, now precisely the point of the position is on the implementation of human rights in the economic field for the welfare of citizen to increase. The effect of economic concept of the global economy and the development of information technology capable of passing the

28 Dede Kania, Hak Asasi Perempuan dalam Peraturan Perundang-Undangan Di Indonesia The Rights of Women in Indonesian Laws and Regulations, Jurnal Konstitusi, Volume 12, No. 4, December 2015, page. 727 
administrative boundaries and State jurisdiction, resulting in the melting point of human rights People in the economic field are increasing. The increase is both in terms of quantity and quality.

In Indonesian Constitution, namely the constitution of the Republic of Indonesia 1945, acknowledge and guarantee the existence and sustainability of the rights of its citizens and other citizens as long as he lives in Indonesia. The formulation of the Indonesian Constitution is in line with the Universal Declaration of Human rights and the Major conventions of the United Nations in human rights field (Adnan Buyung Nasution, 2011).

Employment for women in the informal sector, is prone to human rights violations. In the domestic and Informal sectors of Women Labor, many violations of human rights such as physical, mental, and working hours exceed 8 (eight) hours a day, unpaid salary, sexual harassment, not given time to worship, no opportunity to contact with its environment and closure Communication access for her family. Specifically, the rights of women, are still not fully implemented, when viewed from the context of the application of the Constitution of the state and the laws relating to the foundation and gender Equality. Equality and Elimination of discrimination toward the legal equation of women, still more stop, only on the level of government policy and new in the inclusion in the regulatory clauses on gender equality. Therefore, if viewed from the aspect of gender Equality and its implementation to obtain the same opportunity in the economic field of Indonesian women still continue to struggle. Such conditions are also possible for women in other Asian countries, even in the Middle East countries or possibly in certain African, American and European continent countries. Therefore the struggle and the movement seize equality of rights and opportunities in the field of economics for women of the world continue to move. The movement is no longer an incidental and without the concept of the vision of a mission that is mature, but it has been tangible as a comprehensive female movement and structured with a clear vision of mission.

Issues on human rights, women's rights and opportunity to achieve economic opportunities for women, is a very central issue for Development Interests Economics either globally or regionally. The biggest obstacle for Indonesian women today is still dominated by Patriarchy culture which still prioritizes men as first-class citizens. Changing cultures and cultures of patriarchy is not easy, because it disregarded the spirit, heart and moral that has been believed to be true and is considered to be no problem. In the implementation sector right to access work that implicates the Family Economy, women with low education and no skills, economic Access opportunities that can be Impenetrable is only on employment in the informal or domestic sectors. Employment opportunities for women in the domestic sector or the informal sector will only provide a small and insignificant change in economic and Economic security for women himself 
and his family. Employment for women in the informal or domestic sectors, is prone to human rights violations. In the domestic and Informal sectors of women Labor, many violations of human rights such as physical, mental, and working hours exceed 8 (eight) hours a day, unpaid salary, sexual harassment, not given time to worship, no opportunity to related with its environment and closure Communication access for her family.

Based on the explanation above, human rights issues in the economic field, it is still a major problem for its implementation so that the similarity of rights without discrimination to access the potential Country Economy. On the other hand the issue of female workers struggling as overseas workers to improve the family economy also poses a long and complicated problem. Issues that arise are not only legal issues but arise in the implications of complex psychological and social problems. The issue of poverty, low education and many unemployment and narrow employment, encouraged the birth of many migrant workers abroad. Migrant workers abroad are very prone to the practice of trafficking people especially women and children. Now many of the modes of birth of the female Labor embarkation is actually the practice of women's trafficking.

\section{Women's Trade Prevention and Handling, Towards Gender Equality of Justice In Economic Field}

According to law in Indonesia Women's trade is defined as the Act of hiring transporting, shelter, shipping, transferring or receiving someone with threats of violence, use of Violence, misrepresentation, fraud, counterfeiting, fraudulent, abuse of power or vulnerable positions, debt-making or payment-making,or benefits, thereby obtaining consent of manywho are in control of others, whether in the country or between countries, for the purpose of exploitation or cause of exploitation. From that definition there are three main things as elements of trading people: ${ }^{29}$

a. Moving people both inside andoutside the country's boundaries, including recruitment, carriage, shelter, delivery, transfer or reception;

b. Use the unlawful manner, with the threat of violence, the use of violence, redistribution, transmission, counterfeit, fraud power abuse, or position vulnerable, debt or grant-making, or benefits, thus obtaining the approval of many who hold control over the other person;

c. The intention to exploit or cause exploited persons.

The definition of exploitation is an act with or without a victim's consent including but not limited to prostitution, labour or forced service, slavery or slavery-related practices, Suppression, extortion, physical, sexual exploitation, Reproductive organs or against the law of moving or transplantation of organs and/ or tissues of the body or utilizing power or

29 Fuad Mustafid, Perdagangan Orang dalam Perspektif HAM dan Filsafat Hukum Islam, Al-Ahkam, Volume 29 No. 1, April 2019, page. 91-92 
ability a person by another party to benefit both materil and immateril. The understanding of the trade of persons set out in the Indonesian state regulation above, has been adapted to several United Nations conventions relating to the issue of women's trade and children, there are several forms of trafficking, which is the mode of crime, namely: ${ }^{30}$

a. Both legal and illegal migrant workers;

b. Household worker/informal sector worker;

c. Commercial sex workers/sexual exploitation (including pedophilia);

d. Adoption of false children;

e. Bride order;

f. Beggar;

g. Pornography and drug industry;

h. Organ-repellent.

The occurrence of trafficking in women and children in Indonesia, generally starts from Migration Activities (Musda Mulia, 2004). Globalization and the advancement of information technology capable of blink of an eye to bring closer to the cross border and to bring communication closer to people through administrative boundaries and State jurisdiction. This opportunity and ease of migration, then exploited and exploited by people or syndicate of women's trade Network.

Many cases in the country of Indonesia, the occurrence of the trafficking of women, is a form of migration carried out by deception, with either physical, mental or sexual violence. Even there is also done in marriage mode but then commercialized sexually and accompanied by threats and the closure of access and communication with family and outside parties Anywhere.

Based on the results of the research of Siti Muflichah and Rahadi Wasibintoro, Indonesian women who are targeted to trade People are: ${ }^{31}$

a. Young women of poor families;

b. Women with the condition of her parents are deceased;

c. Widows or women who were divorced;

d. Women with low education;

e. Girlswith limited skills;

f. Women who are being oversekonomi;

g. Sex workers who think that working abroad are more financially promising and provide more enjoyable life expectancy.

The characteristics of individuals who become commercial sex workers through the network of trafficking, are revealed several facts, namely: ${ }^{32}$

30 Farhana, Aspek Hukum Perdagangan Orang di Indonesia, Sinar Grafika, Jakarta, 2010, page.20

31 Siti Muflichah, Rahadi Wasi Bintoro, Trafficking: Suatu Studi Tentang Perdagangan Perempuan Dari Aspek Sosial, Budaya Dan Ekonomi Di Kabupaten Banyumas, Jurnal Dinamika Hukum, Volume 9 No.1, Januari 2009, page. 128 32 Ibid. 
a. In general commercial sex workers are derived from families with low economic levels, i.e. people with rough jobs because they do not have farmland and do not have capital to work as well as unemployment because they do not have Low skills and education;

b. Never experienced emotional wounds, such as heartache because of betrayal of men or because of divorce that was forced due to difficulties in fulfilling the needs of the family economy;

c. Marriage at an early age resulting in divorce, so that the widow's woman should seek economic livelihood in her own way of becoming a commercial sex worker through the network of People's trade.

A more Complex issue experienced by women migrant workers in the informal sector has provided a lot of data, that they are not just a female Workforce working on the path Legal course, but many of them work through the illegal path and are a form of trafficking activities. Sometimes women workers themselves are unaware and do not know that they are victims of trafficking people. They were only aware of trafficking victims especially women's trafficking when experiencing serious problems and unable to Cope themselves.

Migrant workers in the informal sector is one of the entrances for the establishment of people's trade practices through the administration of Labor delivery of women abroad. ${ }^{33}$ From the results of the authors ' interviews with former female migrant Workers, the authors informed that the migrant Labor treatment in the Informal sector has suffered many rights violations Human rights, such as: physical, mental, sexual abuse, long working hours exceed 8 (eight) hours a day, even on average of 20 (twenty) hours. A day, it is not given time for rest, the hours of the night's sleep is from 5 (five) hours, should not communicate with the outside world even though just out of the house, can not communicate and connect with fellow workers of women, may not use and access communication devices, seized passports and visas, Salary Payments unsuitable agreements and preliminary agreements and salaries are not provided.

Data of Indonesian workers, working abroad in Indonesia, based on real data from national bodies of placement and protection of Indonesian Workers (BNP PTKI) throughout the year 2016, are able to provide an overview, That Indonesian women have most Total number of men working outside the country. The majority of Indonesia women work in the informal sector which is very prone to trafficking in people and receives human rights abuses. There are 5 (five) countries that become the work destination of the Indonesian workers who occupy 5 (five), based on the number of recruitment of either male or female workers. Based on the data below the number of Indonesian workers remains dominated by women and It is more

33 Parjoko, Maswita Djaja, dan Soetedjo Yuwono, Penghapusan Perdagangan Orang (Trafficking in Persons) di Indonesia, Kementerian Koordinantor Bidang Kesejahteraan Rakyat, 2005, page.4. 
work in the informal sector. Malaysia ranks first and the greatest recruit of Indonesian work with numbers 87.598, Taiwan's second order with the number 77,087, followed by the third order of Singapore with the amount of 17,700 , The fourth order is Hongkong with 14,434 and the fifth order is Saudi Arabia with the number 13,538. ${ }^{34}$ Data on the recipient of Indonesian workers and the number of Indonesian workers, has been able to provide a reference to the activist mobilizer for migrant Labor Protection to perform problem Mapping More accurate and more focused because the placement of Indonesian workforce can be accessed through official data from the National agency of placement and protection of manpower Indonesia(BNPPTKI). Look at the table below:

\begin{tabular}{|c|c|c|c|}
\hline \multicolumn{4}{|c|}{ JUMLAH TKI MENURUT KAWASAN TAHUN 2016} \\
\hline KAWASAN & LAKI-LAKI & PEREMPUAN & JUMLAH \\
\hline Asia Pasifik dan Amerika & 78.522 & 133.725 & 212.247 \\
\hline Malaysia & 48.309 & 39.289 & 87.598 \\
\hline Singapura & 27 & 17.673 & 17.700 \\
\hline Brunei Darussalam & 5.019 & 3.133 & 8.152 \\
\hline Hongkong & 9 & 14.425 & 14.434 \\
\hline Taiwan & 18.567 & 58.520 & 77.087 \\
\hline Korea Selatan & 5.643 & 269 & 5.912 \\
\hline Jepang & 67 & 8 & 75 \\
\hline Macau & 23 & 11 & 34 \\
\hline Amerika Serikat & 219 & 30 & 249 \\
\hline Lain-Lain & 639 & 367 & 1.006 \\
\hline Timur Tengah dan Afrika & 9.226 & 11.004 & 20.230 \\
\hline Arab Saudi & 7.593 & 5.945 & 13.538 \\
\hline UEA & 250 & 2.325 & 2.575 \\
\hline Kuwait & 174 & 813 & 987 \\
\hline Bahrain & 49 & 74 & 123 \\
\hline Qatar & 647 & 708 & 1.355 \\
\hline Oman & 44 & 970 & 1.014 \\
\hline Yordania & 5 & 60 & 65 \\
\hline Yaman & - & - & - \\
\hline Afrika & 10 & 6 & 16 \\
\hline Lain-Lain & 454 & 103 & 557 \\
\hline Eropa & 1.311 & 663 & 1.974 \\
\hline Italia & 821 & 30 & 851 \\
\hline Spanyol & 121 & 5 & 126 \\
\hline Belanda & 28 & - & 28 \\
\hline Inggris & 1 & 1 & 2 \\
\hline Jerman & 101 & 7 & 108 \\
\hline Lain-Lain & 239 & 620 & 859 \\
\hline \multirow[t]{2}{*}{ Jumlah Total } & 89.059 & 145.392 & 234.451 \\
\hline & \multicolumn{3}{|c|}{ SUMBER: BNP2TKI } \\
\hline
\end{tabular}

Non-governmental organizations in Indonesia, which are concerned with the Prevention of Women's trafficking and focus on the handling of Labor covert through women's trade Practice mode successfully accessing Data from the National agency of placement and protection of Indonesian workers (BNP PTKI) presented above, finally become referral Agenda for prevention in the coming year and referral for the handling in the year, which is directly monitored in the Indonesian Labor recipient Countries that are prone to trafficking of people.

Ministry of Manpower of Indonesia, has published a module for the training of Indonesian labour supervision that is prone to treat forced labour

34 https://www.bi.go.id/seki/tabel/TABEL5 30.pdf accessed on January 2021. 
through crimes mode of trade people. The module material partially accesses the data and source of information from the international labour organization. There are several sectors of employment that include vulnerable worker categories, to be exploited and practiced by forced labour practices. While forced labour has been detected in various Industries and affects workers in formal and informal work relationships, there are certain categories of workers are more vulnerable than others. Some workers will be very difficult to reach, because of their isolated workplace and the privacy principles of private homes that should not be contested and inspected. The employment Supervisor, in line with its mandate and surveillance system coverage, must pay attention to the specific matters of the working group as follows:

a. Workers who are part of a group experiencing the patterns of documented discrimination in the workplace, such as the workers of indigenous peoples in Latin America, Rome in Europe or castes and Tribes in South Asia;

b. Women workers who are often discriminated against and tend to work in economic sectors vulnerable to exploitation include forced labour, such as textiles and garment or Household work as an informal sector worker;

c. As vulnerable groups, child labour consists of young people who do not meet the minimum age requirements of work and do work in acceptable forms of work. The principle that none of the children can work in one of the worst forms of Employment by child labour, as defined in the ILO Convention No. 182. According to the ILO Convention No. 138, the employment Supervisor must understand the special conditions of child labour as well as the worst forms of child labour that are closely related to the work forced and human trafficking.

The current global economic challenge is that it is increasingly difficult to detect and identify human movements through both legal and illegal migration flows. There are several new modes of data obtained by the Indonesian Ministry of Manpower, which concern the pattern of sending workers, which includes the practice of trafficking in persons and forced labor or the pattern of modern slavery. This is reflected in the things that are revealed as below: ${ }^{35}$

a. The latest forms of forced labour penetrate key economic sectors through intricate supply chains and unusual human movements across borders to find work;

b. Forced labour and trafficking are a gross breach of human rights and the rights of workers and people. Forced labor is the antithesis of a decent job. Exemption from forced labour is one of the four

35 Eddyono, Supriyadi Widodo, Perdagangan Manusia dalam Rancangan KUHP, ELSAM and The Asia Foundation dan USAID Jakarta, 2005, page.35 
fundamental rights of workers. The employment supervisor should be tasked to prevent, anticipate, enforce rules and protect workers;

c. Forced labour and the trafficking of people make enormous profit and lead to large economic gains and can be attributed to other illegal activities such as tax evasion and fraud of social benefits;

d. Employment supervisors can enter the workplace which is subject to inspection, without requiring a search warrant and also have some freedom to take action. It is as capital to be an important partner for competent law enforcement;

e. The employment supervisor has an important role to play in preventing forced labour and the protection of victims and victims ' rehabilitation. Therefore, the employment supervisor is an important partner of the government agency, entrepreneur and organizational organization as well as non-governmental organizations, who work with the main tasks and functions in the prevention, enforcement, handling and rehabilitation related to issues of forced labour and trade, especially women and children's trafficking.

The most important function of the employment Supervisor is to ensure compliance with national labor laws. In Relation to forced labour and trafficking, Employment Supervisors often lack a clear mandate. Firstly, because forced labour and trafficking in many countries is a criminal offence generally investigated by police as law Enforcement officers. Second, scope of the employment Supervision system does not cover the potential forced labour practices, such as agriculture, household / Employment the informal sector and the sex industry. There is also a gap between the legal provisions and its application. Mandating Employment Supervisors to fight forced labour and trafficking, particularly the covert practices of women's trafficking, requiring strong political desires to strengthen the manpower surveillance system comprehensively and simultaneously.

In some countries it prohibits forced Labor and trafficking in people, and even specifically gives birth to the Prohibition of trafficking especially women and children. The state of Indonesia has the laws of Republic of Indonesia No. 12 of 2017 about the ratification of ASEAN Convention Against Trafficking In Persons, Especially Women And Children. In the regulation of Indonesian Labour, the trafficking is a form of criminal offence threatened with criminal penalties. Countries that have only anti-trafficking regulations, which are poured in the code of criminal Law, should be Lex specialist in the Employment Law, it is specifically set about the definition of trade of people especially women and children, which is camouflage with trade with the purpose of working exploitation.

Given the complexity of the crime, it may be quite difficult to give responsibility to one Special Ministry. Forced labour is usually under Ministry of Manpower while trading people are often under the ministry of Home Affairs and Foreign ministry when the local trade locus is outside 
administrative boundaries and state jurisdiction. The trading of people who are special victims are women and children, usually dealt with in particular the rehabilitation of the ministry that has a concern for women's empowerment. Therefore, policy coordination is crucial for the handling of trafficking and especially women to be prevented and anticipated early.

The three main operational Objectives of Indonesian labour Supervisor, relevant in Global efforts against forced labour and trafficking in mainly women's trafficking, including: prevention, prosecution and protection. Strengthening and improving the competency of Human Resources of the manpower supervisory Indonesia must be done, in order to be able to:

a. To increase understanding of employment supervisors regarding forced labour and trafficking especially Women's trafficking. Improve The ability and skills to identify victims of trafficking and especially the prevention of Women's trafficking through the recruitment mode of Labor either legally or illegal;

b. To improve cooperation among Manpower Supervisors, police as law Enforcement officers and relevant other stakeholders, in order to conduct Systematic coordination and build The vision of the same Mission for the prevention, prosecution and protection of trafficking of people especially women's trafficking;

c. To explore linkages between the family economy, the national economy and the global economy with the increasing number of female trafficking victims.

Based on the results of the report from data Indonesia Migrant Care, that is now emerging new mode of women trafficking crimes, through the work of internship fraud for School Children and the journey of Umrah during Ramadan and at the time of the hajj departure. His capital abusing Umrah and Hajj visas. According to data from Indonesian Ministry of Foreign Affairs around 5 (five) last year not less than 123,486 Indonesian citizens who were deportations from Saudi Arabia due to over stayers. These, $71 \%$ $(88,737)$ of whom are migrant Women, while $29 \%(34,749)$ People are entered through the Umrah group. The human business by using and misused Umrah and Hajj visas, not only cause social problems but also cause complex legal issues that are trafficking people and people smuggling.

According to one point Palermo/ Convention Palermo Protocol that the trafficking of people is an extraordinary crime, and not only a local problem of one country only, but already Penetrate Migration between countries in certain regions even world countries. People's trafficking is an extraordinary crime, because there are many exploitations, violations of human rights, discrimination and injustice, by utilizing the vulnerable conditions of victims the majority are women.

A much-involved migration phenomenon involving women, either in a legal or illegal way, is also known as the term feminization of migration. This 
Feminization migration is the impact of poverty. Women are forced to be poor because of circumstances with all its limitations and therefore must accept all consequences of his poverty. As a result of poverty, women who are in a helpless condition, but must dare to take risks, to continue the life for either personal or family self. This fact gives the injustice of feminism, and becomes a National problem or even international problem. The feminization of migration, is very likely to produce exploitation either physical, mental or sexual. Such exploitation is the most intrinsic violation of human rights and causes feminist injustice. Data from The national agency of placement and protection of Indonesian Workers (BNP PTKI), every year the average migrant workers of women reaches $53 \%$, thus actually there is a feminization Migration.

The vulnerability of the family economy contributed to a substantial contribution to the vulnerability of women's rights violations and feminism injustice, when women became migrant workers, whether migrant workers or a women's illegal trading mode. Economic Resilience and safety of the family Economy is a fundamental base that will ensure the Justice of feminism and eliminate human rights violations (Anis Hidayah, 2018). The feminist of migration, mostly migrant Workers in the informal sector, has been able to contribute to remittance which is not small, therefore often migrant workers are dubbed foreign exchange hero.

According to the World Bank report in 2017, the estimated number of Indonesian workers reaches 3 (three) to 9 (nine) million people. In the same year the World Bank also provides data reports that the largest majority of female migrations of women, have been able to contribute greatly to Economic growth Nationwide. The donated remittance is 118 trillion or the equivalent of 8.9 billion US dollars. The Remittance is generated by the feminist migration with a risk betting against the treatment that violates human rights and the discrimination of feminism Justice. The remittance Fund is sufficient to contribute to encouraging national economic growth, although often the state is not rapidly present when the legal issues befall migrant workers. It is one of the focus themes for feminist fighters who are moving for feminist Justice in economics to prevent women's trade practices that violate the rights human rights.

\section{CONCLUSION}

Human Rights issues in the economic field, is still a Major problem for its implementation in order to materialize the similarity of rights without discrimination to access economic potential of the country. The human right in the economic field of ideas and ideals is still a willingness of political government that is contained in the constitutional clause of the state. Natural Resources that are the potential for economic enhancement of the community, can only be accessed and enjoyed by a small crowd. Human Rights in the economic field still have to be fought. Women who are largely involved as 
migrant workers, are fighters to gain better economic life. Female workers who struggle as overseas work force to improve the family Economy also pose long and complicated issues. It arise are not only legal issues but arise in the implications of complex psychological and social problems. The issue of poverty, Low education and many unemployment and narrow employment, encouraged the birth of many migrant workers abroad. Migrant workers abroad are very prone to the practice of trafficking people especially women and children. Now many of the modes of birth of the female labour embarcation is actually the practice of women's trafficking. Human rights violations in modern times have evolved into the embodiment of modern slavery by the exploitation of human beings, especially women of migrant Workers. In some countries it prohibits forced Labor and trafficking in people, and even specifically gives birth to the Prohibition of trafficking especially women and children. The state of Indonesia has laws of the Republic of Indonesia No. 12 of 2017 about Ratification of ASEAN Convention Against Trafficking In Persons, Especially Women And Children. In the regulation of Indonesian Labour, The trafficking is a form of criminal offence threatened with criminal penalties. Countries that have only anti-trafficking regulations, which are poured in the code of criminal Law, should be Lex specialist in the Employment Law, it is specifically set about the definition of trade of people especially women and children, which is camouflage with trade with the purpose of working exploitation. According to one point Palermo/Convention Palermo Protocol that the trafficking of people is an extraordinary crime, and not only a local problem of one country only, but already Penetrate Migration between countries in certain regions even world countries. A much-involved migration phenomenon involving women, either in a legal or illegal way, is also known as the term feminization of migration. This Feminization migration is the impact of poverty. Women are forced to be poor because of circumstances with all its limitations and therefore must accept all consequences of his poverty. As a result of poverty, women who are in a helpless condition, but must dare to take risks, to continue the life for either personal or family self. This fact gives the injustice of feminism, and becomes a National problem or even international problem. The feminization of migration, is very likely to produce exploitation either physical, mental or sexual. Such exploitation is the most intrinsic violation of human rights and causes feminist injustice. 


\section{BIBLIOGRAPHY}

\section{Books:}

A. Widiada Gunakaya, 2017, Hukum Hak Asasi Manusia, Penerbit ANDI Yogyakarta;

Eddyono, Supriyadi Widodo, 2005, Perdagangan Manusia dalam Rancangan KUHP, ELSAM and The Asia Foundation and USAID, Jakarta;

Farhana, 2010, Aspek Hukum Perdagangan Orang di Indonesia, Sinar Grafika , Jakarta;

Parjoko, Maswita Djaja, and Soetedjo Yuwono, 2005, Penghapusan Perdagangan Orang (Trafficking in Persons) di Indonesia, Kementerian Koordinantor Bidang Kesejahteraan Rakyat;

Rosyada, Dede, 2003, Pendidikan Kewargaan: Demokrasi, Hak Asasi Manusia and Masyarakat Madani, Prenada Media, Jakarta;

Soetandyo Wignjosoebroto, 2003, Hak-Hak Asasi Manusia: Konsep Dasar and Pengertiannya Yang Klasik pada Masa-Masa Awal Perkembangannya,dalam Toleransi and Keragaman: Visi untuk Abad ke-21 Kumpulan Tulisan tentang Hak Asasi Manusia, Pusat Studi Hak Asasi Manusia Surabaya and The Asia Foundation, Surabaya;

Suharsimi Arikunto, 2006, Prosedur Penelitian Suatu Pendekatan Praktek, Rineka Cipta, Jakarta;

\section{Journals:}

Abu Hanifah, Perdagangan Perempuan and Anak: Kajian Faktor Penyebab and Alternatif Pencegahannya, Sosio Konsepsia, Volume 13 No.2, 2008;

Akhmad Shodikin, Pandangan Hukum Islam and Hukum Nasional Tentang Batas Usia Perkawinan, Mahkamah, Volume 09 No. 1, January-June 2015;

Asih Widi Lestari, Andy Fefta Wijaya, Siti Rochmah, Implementation of Compulsory Study 12 Year Policy to Increase Education Quality in Kudus Regency, Wacana, Volume 18 No. 1, 2015;

Carmen Martínez, Consuelo Paterna-Bleda, Masculinity Ideology and Gender Equality: Considering Neosexism, Anales De Psicología, volume 29 No. 2, May 2013;

Dede Kania, Hak Asasi Perempuan dalam Peraturan Perundang-Undangan Di Indonesia The Rights of Women in Indonesian Laws and Regulations, Jurnal Konstitusi, Volume 12, No. 4, December 2015;

Fuad Mustafid, Perdagangan Orang dalam Perspektif HAM and Filsafat Hukum Islam, Al-Ahkam, Volume 29 No. 1, April 2019; 
Ike Sylvia, Faktor Pendorong and Penarik Perdagangan Orang (Human Trafficking)

Di Sumatera Barat, Humanus, Vol.XIII, No.2, 2014;

Irwan Abdullah, Politisasi Gender and Hak-Hak Perempuan Kendala Struktural Keterlibatan Perempuan Dalam Pencalonan Legislatif, Palastren, Volume 7 No.2, March 2016;

Maftukhatusolikhah, Dwi Budiarto, Pemberdayaan Ekonomi Perempuan Perspektif Gender and Ekonomi Islam: Studi Kasus Akses Pengusaha UMKM Perempuan Terhadap Lembaga Keuangan Syariah BMT Di Palembang, I-Finance, Volume 05 No. 01, July 2019;

Marcellena Nirmala Chrisna Moer, Idin Fasisaka, Putu Titah Kawitri Resen, Implementasi Protokol Palermo Dalam Menanggulangi Permasalahan Tenaga Kerja Wanita Indonesia Yang Menjadi Korban Human Trafficking, Jurnal Hubungan Internasional, Vol 1 No 1, 2016;

Ni Nyoman Sukerti, I Gusti Ayu Agung Ariani, Gst. A. A.Ari Krisnawati, Implikasi Ideologi Gender Dalam Hukum Adat Bali (Studi Di Kota Denpasar), Jurnal Magister Hukum Udayana, Volume 5 No.4, December 2016;

Nurul Husna, Kekerasan Terhadap Perempuan Sebaga Pekerja Migran, Jurnal A/Bayan, Volume 21 No. 30, July-December 2014;

Shinta Dewi Rismawati, Pembangunan Hukum Yang Berkeadilan Gender (Pendekatan Studi Hukum Kritis Bagi Perlindungan Hak Asasi Perempuan Di Indonesia Pasca Ratifikasi CEDAW), Muwazah, Volume 3 No. 3, December 2011,

Sippah Chotban, Azis Kasim, Ketidakadilan Gender Perspektif Hukum Islam, A/Risalah, Volume 20 No. 1, November 2020;

Siti Muflichah, Rahadi Wasi Bintoro, Trafficking: Suatu Studi Tentang Perdagangan Perempuan Dari Aspek Sosial, Budaya and Ekonomi Di Kabupaten Banyumas, Jurnal Dinamika Hukum, Volume 9 No.1, Januari 2009;

Siti Zakiyatul Humairo, Trafficking Woman And Child (Sebuah Kajian Terhadap Hadis-Hadis tentang Trafiking pada Perempuan and Anak), Martabat: Jurnal Perempuan and Anak, Vol. 02, No. 01, July 2018;

Wiwik Sri Widiarty, Perlindungan Hukum Persamaan Hak Asasi Perempuan dalam Meningkatkan Perekonomian Indonesia, Tô-râ, Volume 3 No. 3, December 2017;

\section{Regulations:}


The Criminal Act;

Laws of the Republic of Indonesia No. 12 of 2017 about Ratification of ASEAN Convention Against Trafficking In Persons, Especially Women And Children;

Act No. 13 of 2006 on Witness protection and victim Jo Act No. 31 of 2014 about the protection of witnesses and victims;

Government regulation No. 3 of 2002 about compensation, restitution and rehabilitation of victims of severe human rights violations;

Government regulation No. 44 of 2008 about the provision of compensation and restitution.

\section{Internet:}

https://documents1.worldbank.org/curated/en/738881467782741648/pdf/AUS556 8-P147245-PUBLIC-WomenEntrepreneursinIndonesia-1.pdf

https://www.bi.go.id/seki/tabel/TABEL5 30.pdf

https://www.mkri.id/public/content/persidangan/putusan/22 PUU-XV 2017.pdf 